\title{
Preparation and Characterization of New Amino-Substituted Crowns and Podands
}

\author{
Zeynel Kılıç*,a, Edwin Weber ${ }^{\mathrm{b}}$, Necla Gündüz ${ }^{\mathrm{a}}$, Emine Kılıç ${ }^{\mathrm{a}}$, Hasan Nazıra ${ }^{\mathrm{a}}$, Tuncer Hökelek ${ }^{\mathrm{c}}$, \\ and Mehmet Toy ${ }^{\mathrm{d}}$ \\ a Department of Chemistry, Faculty of Science, University of Ankara, Turkey \\ b Institut für Organische Chemie und Biochemie der Universität Bonn, \\ Gerhard-Domagk-Straße 1, D-W-5300 Bonn 1 \\ c Hacettepe University, Department of Physics, Beytepe, Ankara, Turkey \\ d Hacettepe University, Department of Chemistry, Beytepe, Ankara, Turkey \\ Z. Naturforsch. 47 b, 547-552 (1992); received July 31, 1991 \\ Amino Crowns, Amino Podands, Synthesis, Spectroscopic Studies \\ A number of macrocyclic $(\mathbf{1 b}-\mathbf{3 b})$ and linear oligoether compounds $(\mathbf{4 b}-\mathbf{8 b})$ with 2,2'- \\ methylenebis(4-aminophenol) or 2-aminophenol characteristic building blocks have been syn- \\ thesized by reduction of the corresponding nitro derivatives with $\mathrm{Pd}-\mathrm{C}$ /hydrazine hydrate. \\ The $\mathrm{pKa}^{\prime}$ values of the new compounds have been determined by potentiometric titration. \\ These and the observed spectroscopic data are discussed and compared with related com- \\ pounds. A crystalline 1:1 complex of the diamino crown $\mathbf{3 b}$ with NaSCN has also been pre- \\ pared and characterized.
}

\section{Introduction}

During the last two decades, crown ethers (coronands) [1] and their noncyclic analogues (podands) [1] have been of considerable interest due to the salient complexation properties to cations and uncharged organic molecules [2]. These have found many applications in theoretical, analytical and preparative chemistry [3]. The particular ligation behaviour of crowns and podands depends on different parameters including the number of donor atoms, the nature of donor atoms, ring size as well as topological and conformational parameters [4]. Extra functional groups have also been introduced into crown and podand frameworks in order to make them more specific complexants. Typical examples of compounds are the so-called self-ionizable (protonizable) crowns and podands [5]. Others use the extra functional groups for coloration effects [6]. In these cases the functional groups are intended to converge the complexation site of the crown or podand. By way of contrast, functional groups in a lateral position of the crown are useful to attach additional complexation arms [7] or lipophilic side groups [8], to bind the crown or podand to a polymer backbone [9], to tie to-

\footnotetext{
* Reprint requests to Dr. Zeynel Kılıç.

Verlag der Zeitschrift für Naturforschung,

D-W-7400 Tübingen

0932-0776/92/0400-0547/\$ 01.00/0
}

gether two or more crown compounds (bis-crown ethers) [10] or to build new host topologies [11]. In the latter context, amino functional groups are very promising since they open broad chemical connectivities. However, relatively few coronands and podands with extra amino groups are known [12].

Here, we report on the synthesis of a series of crown compounds $(\mathbf{1 b}-\mathbf{3 b})$ and podands $(\mathbf{4} b-\mathbf{8 b})$ incorporating two aniline building blocks obtained from previously synthesized nitro compounds $(\mathbf{1 a}-\mathbf{8 a})$ [13] and give characterization of the new compounds in respect of analytical, physical, spectroscopic and PKa data; the latter exceed a preliminary study [14]. Crystalline complex formation between $\mathbf{3 b}$ and $\mathrm{NaSCN}$ is reported and since the X-ray crystal structure of dianilino crown $\mathbf{1 b}$ is known [15], a structural comparison based on the previous solid state and the present spectroscopic data in solution is drawn.

\section{Results and Discussions}

\section{Synthesis}

The catalytic reduction of aromatic nitro compounds by hydrazine has been known since 1929 [16]. Numerous aromatic nitro compounds have been treated in neutral or basic solution with hydrazine and in the presence of several catalysts, e.g. $\mathrm{Pd}-\mathrm{C}, \mathrm{Pd}-\mathrm{CaCO}_{3}(1 \%), \mathrm{Pt}-\mathrm{C}, \mathrm{Ru}-\mathrm{Ca}$ or Raney Ni [17]. Selectivity at these reductions is ob- 
served only for aromatic nitro compounds containing O-benzyl, N-benzyl and chloro substituents [18]. So far, no systematic investigation has been made on the hydrazine-effected reduction of cyclic and open-chain oligoether derivatives with two nitro groups on different benzene rings, such as the present compounds $1 \mathbf{a}-7 \mathbf{a}$. These compounds and also $8 \mathbf{a}$ and $\mathbf{1 0} \mathbf{a}$ gave the corresponding diamines $\mathbf{1 b}-\mathbf{8 b}$ and monoamine $\mathbf{1 0} \mathbf{b}$ smoothly and in high yields if the reduction is carried out
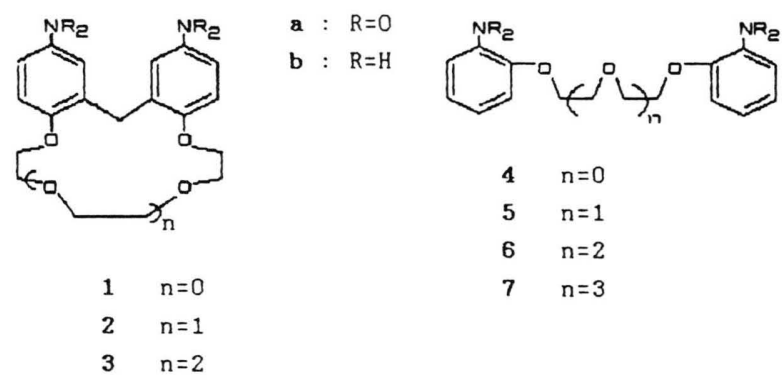

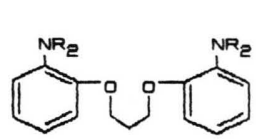

8

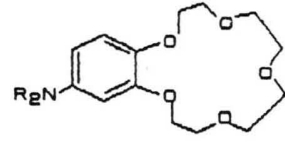

8

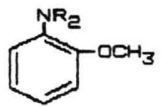

10 in neutral refluxing ethanol solution using hydrazine hydrate $(80 \%)$ and a $\mathrm{Pd}-\mathrm{C}$ catalyst (Table I). However, when nitrobenzo crown ether 9a was subjected to the same reduction conditions, the reduction was very incomplete showing the presence of unreacted nitro compound $\mathbf{9 a}$ and large quantities of intermediate reduction products but only low amount of amine $\mathbf{9 b}$, detected by TLC $\left(\mathrm{CH}_{2} \mathrm{Cl}_{2} / \mathrm{THF}, 1: 1\right)$. The observed difference in reactivity is possibly a result of the particular complexation behaviour of $\mathbf{9 a}$, considering the fact that 18-crown-6 is capable of forming stable complexes with hydrazines [19]. Moreover, it was found that the addition of base $(\mathrm{KOH})$ helps to distinctly speed up the reaction rate. Under this condition, the reductions are generally complete in $0.5-1.0 \mathrm{~h}$, except of 9a which was again insufficient. Hence, reduction of $\mathbf{9 a}$ was alternatively carried out by Raney $\mathrm{Ni} /$ hydrazine hydrate $(80 \%)$ in neutral ethanol to give a $70 \%$ yield of $\mathbf{9 b}$ [20]. Isolation and purification of the amino compounds $\mathbf{1 b}-\mathbf{1 0 b}$ were effected by column chromatography $\left(\mathrm{SiO}_{2}\right)$ using hexane $/ \mathrm{CH}_{2} \mathrm{Cl}_{2}$ (1:2) for elution and subsequent recrystallization (solvents and other experimental data for each compound are given in Table I). Amino crown 9b was obtained as a viscous oil which crystallized hardly from isopropanol in two months at the dark. When dry hydrogen chloride was passed through a solution of $\mathbf{9 b}$ in $\mathrm{CH}_{2} \mathrm{Cl}_{2}$, the corresponding hydrochloride $(\mathbf{9 b} \cdot \mathrm{HCl})$ resulted in crystals (Table I). The 1:1 complex between diamino crown $\mathbf{3} \mathbf{b}$ and $\mathrm{NaSCN}$ was obtained by combining solutions of $\mathbf{3} \mathbf{b}$ in acetonitrile and $\mathrm{NaSCN}$ in hot methanol.

\section{Titration studies}

In previous experiments [14], we have attempted to investigate correlation between structural characteristics and basicity properties of some of the crowns and podands the synthesis of which is re-

Table I. Experimental details for compounds $\mathbf{1 b}-\mathbf{1 0} \mathbf{b}$.

\begin{tabular}{llllc}
\hline Compound & Reaction time (h) & Crystallization solvent & Yield $(\%)$ & M.p. $\left({ }^{\circ} \mathrm{C}\right)[\mathrm{Literature}]^{\mathrm{a}}$ \\
\hline $\mathbf{1 b}$ & 2.0 & Ethanol/Isopropanol $(1: 2)$ & 74 & 169 \\
$\mathbf{2} \mathbf{b}$ & 2.0 & Isopropanol & 73 & 93 \\
$\mathbf{3 b}$ & 2.5 & Isopropanol & 82 & 115 \\
$\mathbf{4 b}$ & 2.0 & Isopropanol & 94 & $128(128)[27]$ \\
$\mathbf{5 b}$ & 2.5 & Ethanol & 92 & $65(65)[27]$ \\
$\mathbf{6 b}$ & 2.5 & Isopropanol & 86 & 33 \\
$\mathbf{7 b}$ & 2.0 & - & 67 & oil (oil) $[28]$ \\
$\mathbf{8 b}$ & 2.0 & Ethanol & 74 & 79 \\
$\mathbf{9 b}$ & 2.0 & Isopropanol & 70 & $75(75)[20]$ \\
$\mathbf{9 b} \cdot \mathrm{HCl}$ & 0.5 & Methylene chloride & 66 & 225 \\
$\mathbf{1 0 b}$ & 1.5 & Isopropanol & 76 & $6(6.22)[26]$ \\
\hline
\end{tabular}

${ }^{\text {a }}$ Literature m.p.'s are in parentheses. 
ported here. Complementary studies including the remaining compounds are required to round off the discussion. They involve using of the same experimental method as before [14]. In this nexus, solutions of the compounds $(0.001 \mathrm{M})$ in nitrobenzene were titrated potentiometrically with perchloric acid $(0.034 \mathrm{M})$ in nitrobenzene and their $\mathrm{pKa}^{\prime}$ values were calculated. The complete $\mathrm{pKa}^{\prime}{ }_{1}$ and $\mathrm{pKa}_{2}{ }_{2}$ data, compounds of comparison included, are given in Table II. For the diamino coronands $\mathbf{1 b}-\mathbf{3 b}$ and podands $\mathbf{4 b}-\mathbf{8 b}$, a linear relationship between the $\mathrm{pKa}^{\prime}{ }_{1}$ values and the present number of oxygen atoms is evident. This suggests that in these compounds, the ether oxygens may considerably be involved in the proton interaction which is reasonable since hydronium complexes of crowns are established [21]. Aniline and 2-methoxyaniline (10b), which were included for comparison, fall into line while $2,2^{\prime}$-diaminobiphenyl shows a distinct deviation, possibly due to a certain proton sponge property [22]. On the other hand, amino crown $\mathbf{9 b}$ with five ether oxygens in the macroring has a $\mathrm{pKa}^{\prime}{ }_{1}$ close to that of $\mathbf{1 b}$ with only three ether oxygens in the ring, which is not obvious from the above reasoning. Also, the $\mathrm{pKa}^{\prime}{ }_{2}$ values found for the series of crowns $\mathbf{1 b}-\mathbf{3 b}$ are difficult to understand.

Consequently, further work is required to establish the effects which control the protonation/deprotonation equilibria of this class of compounds.

\section{Spectroscopy}

Selected IR data for the new amino crowns and podands are listed in Table III. All compounds show characteristic $\mathrm{NH}_{2}$ absorptions at 3500-

\begin{tabular}{llllc}
\hline Compound & $\mathrm{HNP}_{1}[\mathrm{mV}]$ & $\mathrm{HNP}_{2}[\mathrm{mV}]$ & $\mathrm{pKa}^{\prime}{ }_{1}$ & $\mathrm{pKa}^{\prime}$ \\
\hline Aniline & 432 & - & -0.72 & - \\
2,2'-Diaminobiphenyl & 370 & - & +0.29 (for two protons) & - \\
$\mathbf{1 b}$ & 284 & 331 & +1.75 & +0.95 \\
$\mathbf{2 b}$ & 264 & 325 & +2.09 & +1.05 \\
$\mathbf{3 b}$ & 248 & 388 & +2.36 & -0.02 \\
$\mathbf{4 b}$ & 364 & 455 & +0.39 & -1.15 \\
$\mathbf{5 b}$ & 324 & 465 & +1.07 & -1.32 \\
$\mathbf{6 b}$ & 278 & 488 & +1.85 & -1.71 \\
$\mathbf{7 b}$ & 254 & 494 & +2.26 & -1.82 \\
$\mathbf{8 b}$ & 359 & 455 & +0.47 & -1.15 \\
$\mathbf{9 b}$ & 281 & - & +1.80 & - \\
$\mathbf{1 0 b}$ & 407 & - & -0.34 & - \\
\hline
\end{tabular}

Table II. Potentiometric titration data $\mathrm{a}^{\mathrm{a}}$.

Half-neutralization
potentials (HNPs), pKa' ${ }_{1}$
and $\mathrm{pKa}^{\prime}{ }_{2}$ values of var-
ious amines titrated
potentiometrically with
perchloric acid in nitro-
benzene solvent. Poten-
tials recorded against a
buffer solution; readings,
$-17 \mathrm{mV}$ and $\mathrm{pH} 7$.

Table III. Selected IR bands ${ }^{\mathrm{a}, \mathrm{b}}$.

\begin{tabular}{|c|c|c|c|c|c|c|c|}
\hline Compound & $v_{\mathrm{NH}}$ & $v_{\mathrm{C}-\mathrm{H}}($ arom. $)$ & $v_{\mathrm{C}-\mathrm{H}}($ aliph. $)$ & $\mathrm{C}-\mathrm{N}, \mathrm{C}=\mathrm{C}$ & $\begin{array}{l}\mathrm{C}-\mathrm{O}-\mathrm{C} \\
\text { as. (arom.) }\end{array}$ & $\begin{array}{l}\mathrm{C}-\mathrm{O}-\mathrm{C} \\
\text { as. }\end{array}$ & $\begin{array}{l}\mathrm{C}-\mathrm{O}-\mathrm{C} \\
\text { sym. (arom.) }\end{array}$ \\
\hline $1 b$ & $3490 ; 3340$ & 3050 & $2920 ; 2880$ & $1610 ; 1595$ & 1240 & $1140-1090$ & 1045 \\
\hline $2 \mathrm{~b}$ & $3495-3200$ & 3040 & $2915 ; 2875$ & $1620 ; 1595$ & 1235 & $1135-1080$ & 1050 \\
\hline $3 \mathbf{b}^{\mathrm{c}}$ & $3500-3200$ & 3030 & $2910 ; 2880$ & 1630 & 1240 & $1140-1080$ & 1040 \\
\hline $4 b$ & $3460 ; 3380$ & 3080 & 2960 & 1610 & 1230 & $1150-1080$ & 1050 \\
\hline $5 b$ & $\begin{array}{r}3460 ; 3380 \\
.3360\end{array}$ & 3060 & $2960 ; 2880$ & 1610 & 1225 & $1150-1100$ & 1050 \\
\hline $6 b$ & 3495; 3395 & 3070 & 2950; 2900 & $1620 ; 1600$ & 1230 & $1140-1080$ & 1060 \\
\hline $7 b$ & $\begin{array}{r}3480 ; 3380 \\
; 3340\end{array}$ & 3360 & $\begin{array}{l}2960 ; 2870 \\
2910 ; 2850\end{array}$ & $1615 ; 1600$ & 1230 & $1150-1080$ & 1040 \\
\hline $8 b$ & $3500 ; 3400$ & 3070 & $\begin{array}{l}2950 \\
2900\end{array}$ & 1620 & 1230 & $1150-1090$ & 1060 \\
\hline $9 \mathbf{b}^{\mathrm{d}}$ & $3390 ; 3340$ & 3060 & $2920 ; 2870$ & $1610 ; 1600$ & 1235 & $1135-1095$ & 1040 \\
\hline
\end{tabular}

${ }^{\mathrm{a}}$ In $\mathrm{KBr}, v_{\mathrm{cm}}{ }^{-1}$; ${ }^{\mathrm{b}}$ the corresponding nitro derivatives, show $v_{\mathrm{NO}_{2}} 1510,1340 \mathrm{~cm}^{-1}$ bands; ${ }^{\mathrm{c}}$ the corresponding NaNCS complex of $\mathbf{3 b}$ gives a $v_{(\mathrm{C}-\mathrm{N})} 2070 \mathrm{~cm}^{-1}$ band; ${ }^{\mathrm{d}}$ the hydrochloride salt of $\mathbf{9 b}$ gives $v_{\mathrm{NH}_{3} \mathrm{Cl}} 3400$ (broad), 2910, 2870, and $2600 \mathrm{~cm}^{-1}$ bands. 
$3200 \mathrm{~cm}^{-1}$ while the $\mathrm{NO}_{2}$ bands $(1510$ and $1340 \mathrm{~cm}^{-1}$ ) present in the IR spectra of the corresponding nitro derivatives have disappeared [13, 23]. Alkylether and arylether stretching bands are also observed at $1150-1080 \mathrm{~cm}^{-1}$ and $\sim 1240 \mathrm{~cm}^{-1}$, respectively.

The ${ }^{1} \mathrm{H}$ NMR data are given in Table IV (assignment of atoms in Scheme 1).

On comparing the $\alpha-\mathrm{CH}_{2}$ proton chemical shifts of the previously reported [13] nitro coronands and podands with amino coronands and podands, we note a shielding of 0.005 to $0.20 \mathrm{ppm}$ on passing from the nitro to the corresponding amino compounds which is reasonable since $\mathrm{NO}_{2}$ and $\mathrm{NH}_{2}$ are electron withdrawing and donating groups, respectively. A similar, but lesser, effect is observed for the $\beta-\mathrm{CH}_{2}$ and $\gamma-\mathrm{CH}_{2}$ protons.

Benzylic protons give a singlet (average $\delta=$ $3.96 \mathrm{ppm}$ ) in amino derivatives $\mathbf{1 b}-\mathbf{3} \mathbf{b}$ just as the corresponding nitro compounds [13].
The ${ }^{13} \mathrm{C}$ NMR data for the new coronands $(\mathbf{1 b}-$ 3b and 9b) are summarized in Table $\mathrm{V}$ ( $c f$. Scheme 1). It is possible to make a complete assignment of the ${ }^{13} \mathrm{C}$ NMR spectra which furnishes clear proof of the structures. In the ${ }^{13} \mathrm{C}$-proton de-
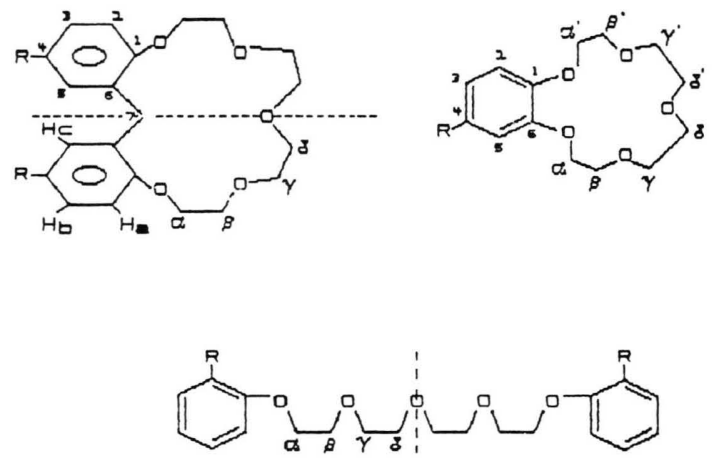

Scheme 1. The numbering scheme of crowns and podands.

Table IV. ${ }^{1} \mathrm{H}$ NMR data $\left(\delta[\mathrm{ppm}]\right.$ and $J_{\mathrm{HH}}[\mathrm{Hz}]^{\mathrm{a}, \mathrm{b}}$.

\begin{tabular}{|c|c|c|c|c|c|c|c|}
\hline Compound & $\alpha-\underline{\mathrm{H}}_{2}$ & $\beta-\underline{\mathrm{H}}_{2}$ & $\gamma-\underline{\mathrm{H}}_{2}$ & $\delta-\underline{\mathrm{H}}_{2}$ & $\mathrm{C}_{2}$ (Benzylic) & $\begin{array}{l}\text { Aromatic protons } \\
(\mathrm{Ha}, \mathrm{Hb}, \mathrm{Hc})\end{array}$ & $\mathrm{NH}_{2}\left(\mathrm{NH}_{3}\right)^{+}$ \\
\hline 1b & $4.05(\mathrm{t}, 4 \mathrm{H}, J=5.0)$ & $3.75(\mathrm{t}, 4 \mathrm{H}, J=5.0)$ & - & - & $3.94(\mathrm{~s}, 2 \mathrm{H})$ & $\begin{array}{l}6.80(\mathrm{~d}, 2 \mathrm{H}, \mathrm{Ha}) \\
6.60(\mathrm{dd}, 2 \mathrm{H}, \mathrm{Hb} \\
J \mathrm{ab}=8.5, J \mathrm{bc}=2.5) \\
6.50(\mathrm{~d}, 2 \mathrm{H}, \mathrm{Hc})\end{array}$ & $3.10(\mathrm{bs}, 4 \mathrm{H}$ \\
\hline $2 b$ & $4.05(\mathrm{~m}, 4 \mathrm{H})$ & $3.78(\mathrm{~m}, 4 \mathrm{H})$ & $3.75(\mathrm{~s}, 4 \mathrm{H})$ & - & $3.98(\mathrm{~s}, 2 \mathrm{H})$ & $\begin{array}{l}6.72(\mathrm{~d}, 2 \mathrm{H}, \mathrm{Ha}) \\
6.50(\mathrm{dd}, 2 \mathrm{H}, \mathrm{Hb} \\
J \mathrm{ab}=8.5, J \mathrm{bc}=3.0) \\
6.40(\mathrm{~d}, 2 \mathrm{H}, \mathrm{Hc})\end{array}$ & $2.65(\mathrm{bs}, 4 \mathrm{H}$ \\
\hline $3 \mathbf{b}$ & $4.05(\mathrm{~m}, 4 \mathrm{H})$ & $3.78(\mathrm{~m}, 4 \mathrm{H})$ & $3.75(\mathrm{~s}, 8 \mathrm{H}$ & $\left.\gamma-\underline{\mathrm{H}}_{2}+\delta-\underline{\mathrm{H}}_{2}\right)$ & $3.96(\mathrm{~s}, 2 \mathrm{H})$ & $\begin{array}{l}6.70(\mathrm{~d}, 2 \mathrm{H}, \mathrm{Ha}) \\
6.50(\mathrm{dd}, 2 \mathrm{H}, \mathrm{Hb} \\
\mathrm{Jab}=8.5, J \mathrm{bc}=3.0) \\
6.32(\mathrm{~d}, 2 \mathrm{H}, \mathrm{Hc})\end{array}$ & $2.30(\mathrm{bs}, 4 \mathrm{H}$ \\
\hline $4 b$ & $4.20(\mathrm{~s}, 4 \mathrm{H})$ & - & - & - & - & $6.70-7.00(\mathrm{~m}, 8 \mathrm{H})$ & $3.80(\mathrm{bs}, 4 \mathrm{H}$ \\
\hline $5 b$ & $4.15(\mathrm{t}, 4 \mathrm{H}, J=5.0)$ & $3.85(\mathrm{t}, 4 \mathrm{H}, J=5.0)$ & - & - & - & $6.50-7.00(\mathrm{~m}, 8 \mathrm{H})$ & $3.70(\mathrm{bs}, 4 \mathrm{H}$ \\
\hline $6 \mathrm{~b}$ & $4.15(\mathrm{t}, 4 \mathrm{H}, J=5.0)$ & $3.85(\mathrm{t}, 4 \mathrm{H}, J=5.0)$ & $3.80(\mathrm{~s}, 4 \mathrm{H})$ & - & - & $6.50-7.00(\mathrm{~m}, 8 \mathrm{H})$ & $3.68(\mathrm{bs}, 4 \mathrm{H}$ \\
\hline $7 b$ & $4.10(\mathrm{t}, 4 \mathrm{H}, J=5.0)$ & $3.83(\mathrm{t}, 4 \mathrm{H}, J=5.0)$ & $3.76(\mathrm{~s}, 8 \mathrm{H}$ & $\left.\gamma-\mathrm{CH}_{2}+\delta-\mathrm{CH}_{2}\right)$ & - & $6.50-6.95(\mathrm{~m}, 8 \mathrm{H})$ & $3.65(\mathrm{bs}, 4 \mathrm{H}$ \\
\hline $\mathbf{8 b}$ & $4.21(\mathrm{t}, 4 \mathrm{H})$ & $2.26(\mathrm{q}, 2 \mathrm{H})$ & & & & $6.70-7.00(\mathrm{~m}, 8 \mathrm{H})$ & $3.75(\mathrm{bs}, 4 \mathrm{H}$ \\
\hline $9 \mathrm{~b}$ & $4.05(\mathrm{~m}, 4 \mathrm{H})$ & $3.80(\mathrm{~m}, 4 \mathrm{H})$ & $3.65(\mathrm{~s}, 8 \mathrm{H}$, & $\left.\gamma-\underline{\mathrm{C}}_{2}+\delta-\underline{\mathrm{H}}_{2}\right)$ & - & $\begin{array}{l}6.60(\mathrm{~d}, \mathrm{Ha}) \\
6.20(\mathrm{~d}, \mathrm{Hc}) \\
6.10(\mathrm{dd}, \mathrm{Hb} \\
J \mathrm{ab}=8.0, J \mathrm{bc}=3.0)\end{array}$ & $3.10(\mathrm{bs}, 2 \mathrm{H}$ \\
\hline $9 b \cdot \mathrm{HCl}$ & $4.20(\mathrm{~m}, 4 \mathrm{H})$ & $3.95(\mathrm{~m}, 4 \mathrm{H})$ & $3.77(\mathrm{~m}, 8 \mathrm{H}$ & $\left.\gamma-\underline{\mathrm{CH}}_{2}+\delta-\underline{\mathrm{H}}_{2}\right)$ & & $\begin{array}{l}6.96(\mathrm{dd}, \mathrm{Hb} \\
\mathrm{Jab}=7.0, J \mathrm{bc}=2.0) \\
7.04(\mathrm{~d}, \mathrm{Ha}) \\
7.09(\mathrm{~d}, \mathrm{Hc})\end{array}$ & {$[2.08(\mathrm{~s}, 3 \mathrm{H})]$} \\
\hline $10 \mathrm{~b}$ & 3.70 & - & - & - & - & $6.50-7.10$ & 3.50 \\
\hline
\end{tabular}

${ }^{\mathrm{a}}$ In $\mathrm{CDCl}_{3}$ (room temperature) at $199.5 \mathrm{MHz}$; ${ }^{\mathrm{b}}$ bs: broad singlet, s: singlet, d: doublet, t: triplet, q: quintet. 
Table V. ${ }^{13} \mathrm{C}$ NMR data $\left(\delta[\mathrm{ppm}], J_{\mathrm{CH}}[\mathrm{Hz}]\right)^{\mathrm{a}, \mathrm{b}}$.

\begin{tabular}{llllllllllll}
\hline $\begin{array}{l}\text { Compd. } \\
\text { No. }\end{array}$ & & $\mathrm{C}_{\alpha}$ & $\mathrm{C}_{\gamma}$ & $\mathrm{C}_{\delta}$ & $\mathrm{C}_{1}$ & $\mathrm{C}_{2}$ & $\mathrm{C}_{3}$ & $\mathrm{C}_{4}$ & $\mathrm{C}_{5}$ & $\mathrm{C}_{6}$ & $\mathrm{C}_{7}$ \\
\hline $\mathbf{1 b}$ & 71.56 & 69.07 & - & - & 147.45 & 112.76 & 116.50 & 142.31 & 118.08 & 132.78 & 28.38 \\
$\mathbf{2 b}$ & 69.34 & 68.82 & 68.82 & - & 149.02 & 112.87 & 113.93 & 139.74 & 117.23 & 130.63 & 28.50 \\
$\mathbf{3 b}$ & 71.16 & 70.66 & 69.79 & 69.09 & 150.15 & 113.44 & 113.44 & 139.81 & 118.00 & 130.99 & 29.23 \\
$\mathbf{9 b}$ & 68.79 & 67.47 & 67.40 & 67.08 & 147.54 & 112.56 & 106.97 & 122.01 & 114.80 & 147.14 \\
& $68.17\left(\alpha^{\prime}\right)$ & $\left(\beta, \beta^{\prime}\right)$ & $\left(\gamma, \gamma^{\prime}\right)$ & $\left(\delta, \delta^{\prime}\right)$ & & & & & & \\
\hline
\end{tabular}

${ }^{a}$ In $\mathrm{CDCl}_{3}$ (room temperature) at $50.10 \mathrm{MHz}$; ${ }^{1} J_{\mathrm{CH}}$ (aliph.) $=\sim 142 \mathrm{~Hz},{ }^{3} J_{\underline{\mathrm{CCCH}}}=4.5-5.0 \mathrm{~Hz},{ }^{1} J_{\underline{\mathrm{CH}}}(\mathrm{arom}$.) $=$ $\sim 165 \mathrm{~Hz}$.

\begin{tabular}{|c|c|c|c|c|c|c|}
\hline \multirow[b]{2}{*}{ Compound } & \multirow[b]{2}{*}{ Formula } & \multirow[t]{2}{*}{$\begin{array}{l}\mathrm{M}\left(\mathrm{M}^{+}\right) \\
\text {Calcd (found) }\end{array}$} & \multicolumn{3}{|c|}{ Elemental analysis (\%) } & \multirow[t]{2}{*}{$\begin{array}{l}\text { Table V1. Analytical } \\
\text { data. }\end{array}$} \\
\hline & & & $\mathrm{C}$ & $\mathrm{H}$ & $\mathrm{N}$ & \\
\hline 1b & $\mathrm{C}_{17} \mathrm{H}_{20} \mathrm{~N}_{2} \mathrm{O}_{3}$ & $300(300)$ & $67.98(67.86)$ & $6.71(6.83)$ & $9.33(9.18)$ & \\
\hline $2 b$ & $\mathrm{C}_{19} \mathrm{H}_{24} \mathrm{~N}_{2} \mathrm{O}_{4}^{3}$ & $344(344)$ & $66.26(66.34)$ & $7.02(7.15)$ & $8.13(7.96)$ & \\
\hline $3 \mathbf{b}$ & $\mathrm{C}_{21} \mathrm{H}_{28} \mathrm{~N}_{2} \mathrm{O}_{5}$ & $388(388)$ & $64.93(64.83)$ & $7.27(7.26)$ & $7.21(7.10)$ & \\
\hline 6 & $\mathrm{C}_{18} \mathrm{H}_{24} \mathrm{~N}_{2} \mathrm{O}_{4}^{3}$ & $332(332)$ & $65.04(65.17)$ & $7.28(7.32)$ & $8.43(8.25)$ & \\
\hline 7 & $\mathrm{C}_{20} \mathrm{H}_{28} \mathrm{~N}_{2} \mathrm{O}_{5}$ & $376(376)$ & $63.81(63.72)$ & $7.50(7.61)$ & $7.44(7.34)$ & \\
\hline $8 b$ & $\mathrm{C}_{15}^{20} \mathrm{H}_{18}^{28} \mathrm{~N}_{2} \mathrm{O}_{2}$ & $258(258)$ & $69.75(69.87)$ & $7.02(6.93)$ & $10.84(10.72)$ & a Based on the mass \\
\hline $\mathbf{9 b} \cdot \mathrm{HCl}$ & $\mathrm{C}_{14} \mathrm{H}_{22} \mathrm{NO}_{5} \mathrm{Cl}$ & $319(283)^{\mathrm{b}}$ & $52.58(52.32)$ & $6.93(6.97)$ & $4.38(4.58)$ & of the most abundant \\
\hline $\mathbf{9 b} \cdot \mathrm{NaSCN}$ & $\mathrm{C}_{21} \mathrm{H}_{28} \mathrm{~N}_{3} \mathrm{O}_{5} \mathrm{SNa}$ & $469(388)^{c}$ & $56.28(56.23)$ & $6.01(6.08)$ & $8.95(8.86)$ & $\begin{array}{l}\text { c }\left(\mathrm{M}^{+}-\mathrm{NaNCS}\right) \text {. } \\
\text { Natope; }\end{array}$ \\
\hline
\end{tabular}

coupled NMR spectra of $\mathbf{1 b}-\mathbf{3} \mathbf{b}$, one benzylic and six different aromatic carbon lines have been observed. For the more flexible oligoether segments of the molecules $\mathrm{C} \alpha-\mathrm{C} \delta$ signals, respectively, are separated, with the exception of $\mathbf{9 b}$ where the $C \beta$ and $\mathrm{C} \gamma$ signals overlap.

As determined by X-ray crystallography [15] crown compound $\mathbf{1 b}$ shows a highly non-symmetric irregular conformation in the solid state with high distortion at the benzylic carbon (bonding angle $116.1^{\circ}$ ). The torsion angle between the phenylene planes is $65.6^{\circ}$ and there is short contact (2.41 $\AA$ ) between one of the benzylic $\mathrm{H}$ atom and a neighbouring oxygen, unlike a similar compound of larger ring size [24]. The ${ }^{1} \mathrm{H}$ NMR spectra indicate no such irregular conformations in solution, neither of $\mathbf{1 b}$ nor of $\mathbf{2} \mathbf{b}$ and $\mathbf{3 b}$. This, it is likely that conformations of the higher diphenylmethano crowns are also rather different in solution and in the solid state.

In the electron impact (EI) mass spectra of the amino crowns $\mathbf{1 b}-\mathbf{3} \mathbf{b}$, relative height of $100 \%$ of the $\mathrm{M}^{+}$-peaks (see Table VI) suggests high stability of the macrocycles. Fragmentations mostly pro- ceed by the loss of $\mathrm{C}_{4} \mathrm{H}_{7} \mathrm{O}, \mathrm{C}_{4} \mathrm{H}_{8} \mathrm{O}_{2}$ or $\mathrm{C}_{2} \mathrm{H}_{4} \mathrm{O}$ groups. For the NaNCS complex of $\mathbf{3} \mathbf{b}$, the fragmentation patterns are similar to uncomplexed $\mathbf{3} \mathbf{b}$.

\section{Experimental}

\section{General}

Melting points were measured on a ThomasHoover apparatus using a capillary tube. IR spectra were obtained from a Perkin Elmer 377 spectrophotometer in $\mathrm{KBr}$ discs. ${ }^{1} \mathrm{H}$ and ${ }^{13} \mathrm{C}$ NMR spectra were recorded in $\mathrm{CDCl}_{3}$ solution $(90 \mathrm{MHz}$ and $200 \mathrm{MHz}$ NMR spectrometers, $\delta$-scale, $\mathrm{SiMe}_{4}$ as internal standard). Mass spectra were obtained from a VG 7070 mass spectrometer (electron impact mode $70 \mathrm{eV}$, source temperature $240{ }^{\circ} \mathrm{C}$ ). Microanalyses were carried out by the microanalytical service of TÜBITAK-MAE, Gebze-Kocaeli (Turkey).

\section{Chemicals}

Hydrazine hydrate $(80 \%), \mathrm{Pd}-\mathrm{C}(10 \%)$ and nickel catalyst were purchased from Fluka. 2,2'diaminobiphenyl [25] and the nitro precursors $\mathbf{1 a}-10$ a were prepared by the literature methods 
$[13,25]$. The new amino crowns and podands $\mathbf{1 b}-\mathbf{8} \mathbf{b}$ as well as $\mathbf{9 b}[20]$ and $\mathbf{1 0 b}$ [26] were synthesized from the corresponding nitro derivatives $1 \mathrm{a}-10$ a by catalytic reduction with hydrazine hydrate. Experimental details are summarized in Table I, analytical data in Table VI. The procedure given for the synthesis of $\mathbf{3} \mathbf{b}$ is representative of all amino compounds, except $9 \mathbf{b}[20]$.

\section{Preparation of diamino crown $\mathbf{3} \mathbf{b}$}

To a refluxing suspension of $\mathrm{Pd}-\mathrm{C}(0.10 \mathrm{~g}, 10 \%$ $\mathrm{Pd})$ and dinitro crown $3 \mathrm{a}(0.90 \mathrm{~g}, 2.0 \mathrm{mmol})$ in ethanol $(100 \mathrm{ml})$ was dropped a solution of hydrazine hydrate $(80 \%, 8 \mathrm{ml})$ in ethanol $(50 \mathrm{ml})$ over a period of $0.5 \mathrm{~h}$. Refluxing was continued for $2 \mathrm{~h}$. The mixture was filtered and the solvent removed in vacuo. The residue was subjected to column chromatography $(75 \mathrm{~g} \mathrm{SiO} 2$ to $1.0 \mathrm{~g}$ residue, eluents hexane $/ \mathrm{CH}_{2} \mathrm{Cl}_{2}$ 1:2) to give solid $\mathbf{3 b}$ which was crystallized from isopropanol and recrystallized from ether-isopropanol (1:4).

\section{Hydrochloride of $\mathbf{9} \mathbf{b}$}

This compound was obtained by passing dry hy- drogen chloride through a solution of $9 \mathbf{b}$ in methylene chloride. Further details in Table I and VI.

\section{Preparation of complex $\mathbf{3} \mathbf{b} \cdot \operatorname{NaNCS}(1: 1)$}

The macrocycle $\mathbf{3 b}(0.388 \mathrm{~g}, 1.0 \mathrm{mmol})$ dissolved in acetonitrile $(15 \mathrm{ml})$ was added to a hot solution of NaNCS $(0.081 \mathrm{~g}, 1.0 \mathrm{mmol})$ in methanol $(10 \mathrm{ml})$. The mixture was concentrated and diethyl ether $(10 \mathrm{ml})$ was added. On refrigerating for two days, needle-shaped crystals formed which were collected and washed with cold ether. Recrystallization from acetonitrile/diethyl ether (1:3) yielded $0.33 \mathrm{~g}(70 \%)$ of the $1: 1$ complex, m.p. $>250{ }^{\circ} \mathrm{C}$ (decomp.), analytical data in Table VI.

We are indebted to Prof. Dr. C. Tüzün (University of Ankara, Turkey) for helpful discussions. T. H. thanks Dr. C. K. Prout, Dr. A. K. Cheetham, and Dr. D. J. Watkin of Chemical Crystallography Laboratory, University of Oxford (UK) for Laboratory and computer facilities. E. W. thanks the Fonds der Chemischen Industrie and the Deutsche Forschungsgemeinschaft for financial support.
[1] E. Weber and F. Vögtle, Inorg. Chim. Acta 45, 165 (1980).

[2] R. M. Izatt and J. J. Christensen (eds): Synthesis of Macrocycles - The Design of Selective Complexing Agents; Progress in Macrocyclic Chemistry, Vol. 3, Wiley, New York (1987).

[3] F. Vögtle and E. Weber (eds): Host Guest Complex Chemistry, Macrocycles (Synthesis, Structures, Applications), Springer-Verlag, Berlin (1985).

[4] S. Patai and Z. Rapoport (eds): Crown Ethers and Analogs, Wiley, Chichester (1989).

[5] C. W. Mc Daniel, J. S. Bradshaw, and R. M. Izatt, Heterocycles 30, 665 (1990).

[6] S. Misumi and T. Kaveda, J. Incl. Phenom. 7, 83 (1989); M. Takagi and K. Ueno, in ref. 3, p. 217.

[7] G. W. Gokel and J. E. Trafton, in Y. Inoue and G. W. Gokel (eds): Cation Binding by Macrocycles, Marcel Dekker, New York (1991); E. Weber in ref. 4 , p. 305.

[8] J. Beger and K. Gloe, Z. Chem. 26, 315 (1986); E. Weber, Liebigs Ann. Chem. 1983, 770.

[9] J. Smid, in R. M. Izatt and J. J. Christensen (eds): Progress in Macrocyclic Chemistry, Vol. 2, Wiley, New York (1981).

[10] S. Shinkai and O. Manabe, in ref. 3, p. 245

[11] E. Weber, K. Skobridis, M. Onchi, T. Hakushi, and Y. Inoue, Bull. Chem. Soc. Jpn. 63, 3670 (1990).

[12] G. W. Gokel and S. H. Korzeniowski (eds): Macrocyclic Polyether Syntheses, Springer-Verlag, Berlin (1982).

[13] Z. Kılıç and N. Gündüz, Tetrahedron 42, 137 (1986).
[14] T. Gündüz, N. Gündüz, Z. Kılıç, E. Kılıç, and A. Kenar, Analyst 113, 965 (1988).

[15] T. Hökelek and Z. Kılıç, Acta Crystallogr. C46, 1908 (1990).

[16] M. Bush and K. Schulz, Chem. Ber. B62, 1458 (1929).

[17] A. Frust, R. C. Berlo, and S. Hooton, Chem. Rev. 65, $51(1965)$.

[18] F. Yuste, M. Saldana, and F. Walls, Tetrahedron Lett. 23, 147 (1982).

[19] F. Vögtle and W. M. Müller, Chem. Ber. 113, 2081 (1980).

[20] R. Ungaro, B. El Haj, and J. Smid, J. Am. Chem. Soc. 98(17), 5198 (1976).

[21] H. J. Buschmann, Polyhedron 6, 1469 (1987).

[22] H. A. Staab and T. Saupe, Angew. Chem., Int. Ed. Engl. 27, 865 (1988).

[23] W. O. Lin and M. C. B. V. de Souza, Monatsh. Chem. 112, 253 (1981).

[24] F. A. von Itter, F. Vögtle, G. Weber, and M. Sheldrick, Z. Naturforsch. 38b, 262 (1983).

[25] R. E. Moore and A. Furst, J. Org. Chem. 23, 1504 (1958).

[26] R. C. Weast and M. J. Astle, CRC Handbook of Chemistry and Physics, 60 th Edition, C-116, CRC Press, Boca Raton, Florida 33431.

[27] Z. Kılıç and N. Gündüz, Synth. React. Inorg. Met.Org. Chem. 16(4), 457 (1986).

[28] F. Vögtle and H. Sieger, Angew. Chem., Int. Ed. Engl. 16(6), 396 (1977). 